\title{
EFFECT OF CANKER SIZE ON AVAILABILITY OF CASSAVA PLANTING MATERIALS IN NIGERIA
}

\author{
O.P. OBILO and B. IKOTUN \\ Department of Crop Science and Technology, School of Agriculture and Agricultural Technology, Federal \\ University of Technology, Owerri, Imo state, P.M.B 1526 \\ Department of Crop Protection and Environmental Biology, Faculty of Agriculture and Forestry, \\ University of Ibadan, Oyo state, Nigeria
}

(Received 9 February, 2009; accepted 28 June, 2009)

\begin{abstract}
Cassava (Manihot esculenta L.) production is highly limited by cassava anthracnose disease (CAD) which causes significant losses in planting materials. An experiment was laid out at Ihiagwa, Owern in Nigeria with eighteen treatments replicated three times. Disease severity was scored on a scale of 1-5, and disease incidence was recorded as the percentage of infected plants in each host plant line. In all the three trials, TMS 30211 (425 mm) had cankers high up on the stem, showing that they were infected later in life. This will lead to more disease - free stems. Cultivars Akwakwuru (39.6 mm²), TMS $30555\left(31.6 \mathrm{~mm}^{2}\right)$, and Nwaocha $\left(43.7 \mathrm{~mm}^{2}\right)$, had the large canker size on whole plant, young stem, shoot and maturing stem. These cultivars had low resistance to anthracnose. In all the trials, TMS 4(2)1425, and TMS 30211, had the smallest canker size $\left(1.80\right.$ and $6.3 \mathrm{~mm}^{2}$, respectively) on whole plant, young stems, shoots and maturing stems. TMS 4(2)1425 and TMS 30211 had higher resistance to anthracnose and can be recommended for further improvement through breeding, because plants producing smaller - size lesions survive much longer and would also mature and produce flowers needed for breeding for improving resistance to CAD and other diseases.
\end{abstract}

Key Words: Cassava anthracnose disease, Manihot esculenta, resistance

\section{RÉSUMÉ}

La production de manioc (Manihot esculenta L.) est fortement limitée par la maladie d'anthracnose de manioc (DAO) qui cause des pertes significatives en matières végétales. Une expérience a été présentée avec dix-huit traitements repliés trois fois. La sévérité de la maladie a été marquée sur une échelle de 1-5, et l'incidence de la maladie a été enregistrée comme pourcentage des usines infectées dans chaque ligne d'usine de centre serveur. Dans toutes trois épreuves, TMS 30211 (425 millimètres) a eu des cankers haut vers le haut sur la tige, prouvant qu'ils ont été infectés plus tard dans la vie. Ceci mènera à plus de maladie - tiges libres. Cultivars Akwakwuru, (39.6 millimètres²), TMS 30555 (31.6 millimètres ${ }^{2}$ ), et Nwaocha (43.7 millimètres²), a eu la plus grande taille de canker sur la tige de plantes entières et jeune, pousse et tige de maturation. Ces cultivars ont eu la basse résistance à l'anthracnose. Dans toutes épreuves, TMS 4 (2) 1425, et TMS 30211, ont eu la plus petite taille de canker (1.80 et 6.3 millimètres $^{2}$, respectivement) sur les tiges de plantes entières et jeunes, pousses et tiges de maturation. TMS 4 (2) 1425 et TMS 30211 ont eu une résistance plus élevée à l'anthracnose et peuvent être recommandés pour davantage d'amélioration par la multiplication, parce que production d’usines plus petite - les lésions de taille survivent beaucoup plus longtemps et aussi mûriraient et produiraient des fleurs requises pour multiplier pour améliorer la résistance au DAO et à d'autres maladies.

Mots Clés: La maladie d’anthracnose de manioc, Manihot esculenta, résistance 


\section{INTRODUCTION}

Sub-Saharan Africa grows 55\% of the world production of cassava roots and Nigeria alone contributes $21 \%$ of the total (FAO, 2009). Cassava is a major food staple for humans, provides feed for livestock and is currently a major source of industrial raw materials for high quality cassava flour, starch and ethanol (Okechukwu et al., 2009). This new awareness, coupled with the increased food demand of the rapidly growing population has led to an expansion of cassava cultivation in many African countries (Onyeka et al., 2005).

The major cassava diseases were reported to be cassava mosaic disease (CMD), bacterial blight (CBB), anthracnose (CAD) (Hahn, et al.,1981) and cassava root rot (Lozano and Booth,1974). Its production is highly limited by CAD which causes significant losses in planting materials or total crop failure in extreme cases. Cassava anthracnose is characterised by a dramatic wilting and constriction of the youngest part of the green tender shoots. On older plants oval brown-pale shallow depressions appear on green stems, soon developing into cankers which lead to stems being brittle and collapse under gentle pressure (Ngeve et al.,2005; Obilo et al., 2009).

CAD can cause significant loss in planting materials and total crop failure (Makambila,1987) and several infected stems and seeds in some cases result in a decrease of 20 - $45 \%$ germination (IITA,1990; Fokunang et al., 1999b). Some researchers believe that using infected cuttings as planting materials is likely to have an effect on the yield and that the loss of many leaves and necrosis of young shoots decrease the photosynthetic capacity of affected plants (CIAT,1977; Makambila,1978; Theberge, 1985). This has stimulated interest in developing sufficiently resistant cultivars. The selection and use of resistant cassava cultivars as planting materials appears to be the most efficient means of controlling anthracnose disease (Hahn et al., 1981).

Cassava anthracnose disease is characterised by light to dark -brown oval lesions on the soft green stems and at leaf axils. The latter leads to petiole epinasty, petiole necrosis wilting and defoliation. On older plants the disease is characterised by pale brown shallow depressions on the stems. In old stems, infection occurs as raised round and stringy lesions, which develop into deep cankers. The deeper cankers affect plant-conducting tissues, leading to poor plant vigour, severe wilting, and defoliation (Van der Bruggen and Maraite, 1987; Fokunang, et al., 1999a). Lozano and Booth (1974) and Akinyele and Ikotun (1989) stated that these cankers serve as entry points for other pathogens such as Agrobacterium manihotis, which causes crown gall disease of south America as well as stem, root and tuber-rotting organisms such as Sphaerostilbe repens, Armillaria mellea. Anthracnoses are epidemic diseases characterised by a particular aspect of symptoms (cankers on stems, twigs and fruit, leaf spots and tip dieback) on aerial parts of diseased plants (Massenot and Raynal, 1973). As the stem becomes woody, the depressions develop into deep cankers. Stem deformation occurs in some cultivars, making the stems brittle and easily broken by wind (Ikotun and Hahn, 1991). Deeper cankers sometimes affect the pith of of the plant, resulting in blocked resources circulation (Van der Bruggen and Maraite, 1987). C. gloeosporioides (Penz) f. sp. manihotis Chev. is the causal agent of CAD. This disease is frequently seen in the cassava-growing areas of South America (Lozano and Booth,1974), Africa (Terry and Oyekan, 1976), and Asia (Chandrasekharan et al., 1979). The aim of this study was to assess the effect of the incidence of CAD on the availability of planting materials in relation to the canker size and number.

\section{MATERIALS AND METHODS}

The study was located at the Teaching and Research Farm of the Federal University of Technology, Ihiagwa, Owerri. The University is located between latitudes 5Ú 23'N and 5Ú24'N and longitudes $6^{\circ} 59^{\prime} \mathrm{E}$ and $6^{\circ} 58^{\prime} \mathrm{E}$. The site is situated in the rain forest zone of south-eastern, Nigeria, which is situated at Owerri West Local Government Area, Imo state. The experiment was conducted three times during September, 2003 and August, 2004 (first trial); August, 2004 and October, 2005 (second trial) and September, 2005 and August, 2006 (third trial). 
Thirteen cultivars of cassava were obtained from the International Institute of Tropical Agriculture (IITA), Ibadan. The cultivars were as follows: Tropical Manihot esculenta (TME) 117 (Isunikankiyan), 92/0326, 92/0067, 91/02324, 97/ 3200, 96/1642, 98/0510, Tropical Manihot Selection: (TMS) 91934, 4(2)1425, 30001, 30211, 30572 and 30555 . Two cultivars of cassava were obtained from the National Root Crop Research Institute, Umudike, Umuahia, Abia State. The two cultivars were: National Root (NR) 8212 and NR 8082. Nwaocha, Nwageri and Akwakwuru which are the local varieties were obtained from local farmers at Ihiagwa village, Owerri West Local Government Area. Eighteen cultivars were used for the study.

The experiment was laid out in a randomised complete block design, with eighteen treatments replicated three times. Each plot was $10 \mathrm{~m}$ by $2 \mathrm{~m}$ with a border of $1 \mathrm{~m}$ between plots. Block size was $65 \mathrm{~m}$ by $8 \mathrm{~m}$, with a border of $2 \mathrm{~m}$ between blocks. The ridges, spaced at $1 \mathrm{~m}$ apart, were 30 $\mathrm{cm}$ high and $10 \mathrm{~m}$ long. Stem cuttings of 25 - 30 $\mathrm{cm}$ long were planted $1 \mathrm{~m}$ apart on the ridge crests.

The total plant population density was 10,000 plants per hectare. No fertilisers or herbicides were applied during the study. Hand-weeding was done fortnightly. Between 2 and 6 months after planting (MAP), plants were observed for the natural development of CAD symptoms. The height of the first canker from the ground level was measured with a graduated meter ruler. The length and the diameters of all the cankers on each infected stems were measured with a ruler and the area was calculated using the formula for area of a circle $\left(ð r^{2}\right)$ fortnightly for 6 months. Cankers on the following parts of the stem were measured: shoots, young stems, maturing stems, and matured stems.

The symptoms of the sequence of CAD disease development were observed on green cassava stems from naturally infected plants. These were assessed using the following parameters: disease severity scored on a scale of 1-5 by the method of Ikotun and Hahn (1991); where: 1 = no symptom (resistant); 2 = development of shallow cankers lower on the stem; 3 = development of successive cankers higher up the plant with older cankers becoming larger and deeper; 4 = development of dark brown lesions on green shoots, petioles and leaves. Young shoots collapse and are distorted. $5=$ wilting and drying up of shoots and young leaves and death of part of or whole plant.

Disease incidence in all trials was recorded as the percentage of infected plants in each host plant line (Fokunang, et al., 2001). At the end of 6 MAP, plants were too high and the canopies had closed up, making scoring impracticable.

The final scores were recorded and screening was stopped. The data from the three years were subjected to analysis of variance (ANOVA) using the generalised linear model (GLM) of SAS analytical package. Treatment means were separated using Fisher's protected least significant difference (LSD) at 5\% probability level.

\section{RESULTS}

In the first and third trials, 96/1642 had the lowest distance of the first canker from the ground level of $208.33 \mathrm{~mm}$ (first trial) and $63 \mathrm{~mm}$ (third trial). TMS 91934 had the lowest distance of the first canker from the ground level (Table 1). TME 117 (Isun) and Nwaocha had the highest distance of the first canker from the ground level. TME 117 (Isun) had its first canker from the ground level of $583.3 \mathrm{~mm}$ in the first trial and $2331.2 \mathrm{~mm}$ in the second trial. Nwaocha had its first canker from the ground level in the second trial. TMS 30211 had the highest distance of the first canker from the ground level. TMS 30555 had the lowest distance of the first canker $(555.5 \mathrm{~mm})$ in the second trial and the highest in the first trial.

TMS 4(2)1425 had the smallest canker size overall in both the first and second trials (Table 2). Akwakwuru had the largest canker size in both trials on whole plant. Nwaocha had the smallest canker size of whole plant $\left(2.33 \mathrm{~mm}^{2}\right)$ in the first trial and had the largest canker size of $43.7 \mathrm{~mm}^{2}$ on whole plant in the second trial. TMS 4(2)1425 had the smallest canker size in both the first and second trials on young stems, while TMS 30211 had the smallest canker size on young stems in the first and third trials. TMS 30572 had the largest canker size in both the first and third trials of $6.43 \mathrm{~mm}^{2}$ and $13.2 \mathrm{~mm}^{2}$, respectively, on young stems. TMS 4(2)1425 had the smallest canker size on maturing stem in both the first trial 
TABLE 1. Distance of first canker (DFC) from the ground level at 6 months after plantig at Ihiagwa in Nigeria

\begin{tabular}{lccc}
\hline Variety & & DFC $(\mathrm{mm})$ & \\
\cline { 2 - 4 } & 1 $^{\text {st }}$ trial $(2003 / 04)$ & $2^{\text {nd }}$ trial $(2004 / 05)$ & $3^{\text {rd }}$ trial $(2005 / 06)$ \\
\hline TME 117 (Isuni) & 583.33 & 2331.2 & 0 \\
TMS 30555 & 543.33 & 555.5 & 0 \\
NR 8082 & 510.00 & 729.6 & 0 \\
TMS 4(2)1425 & 433.33 & 565.5 & 0 \\
TMS 30211 & 425.00 & 1531.4 & 079.5 \\
TMS 30001 & 363.33 & 1022.2 & 0 \\
Nwaocha & 333.33 & 1846.3 & 0 \\
98/0510 & 300.00 & 1052.8 & 0 \\
NR 8212 & 300.00 & 2160.4 & 123.0 \\
TMS 30572 & 296.67 & 1355.5 & 0 \\
92/0326 & 246.67 & 2293.7 & 0 \\
92/0067 & 231.67 & 1092.6 & 50.7 \\
TMS 91934 & 225.00 & 783.3 & 03.0 \\
96/1642 & 208.33 & 977.8 & 0 \\
97/3200 & 190.00 & 1381.5 & 0 \\
Nwageri & 183.33 & 933.5 & 0 \\
91/02324 & 160.00 & 1233.3 & 59.12 \\
Akwakwuru & 70.00 & 1331 & \\
& & & 0 \\
LSD 0.05 & 125.6 & 1248.0 & \\
\hline
\end{tabular}

Means followed by the same alphabet in the same column are not significantly different according to $\operatorname{LSD}(P<0.05)$

$\left(1.80 \mathrm{~mm}^{2}\right)$ and second trial $\left(3.8 \mathrm{~mm}^{2}\right)$. TMS 30211 had the smallest canker size on maturing stem, in both the second $\left(12.9 \mathrm{~mm}^{2}\right)$ and third trials $\left(6.3 \mathrm{~mm}^{2}\right)$. TMS 30555 had the largest canker size on maturing stem in both the first and second trials (Table 2).

\section{DISCUSSION}

The three trials showed that moisture remains a very important factor in the incidence and severity of CAD in any year. The evidence being that in the third trial when there was no rainfall (Table 3), the incidence and severity of CAD were low. This was indicated by the distance and size of canker being zero in the third trial. This is in line with the report made by Lozano and Booth (1974) that the geographic distribution of cassava anthracnose depends to some extent on the climatic factors such as rainfall, relative humidity, temperature and wind. Fokunang et al. (1999) also reported higher anthracnose incidence and severity in wet season cassava plantings than in the dry season crop in
Nigeria, and concluded that the pathogen attacks cassava mostly during prolonged periods of rainfall. Fokunang et al. (1999) also stated that in the wet season the distances from the ground to the first stem canker in susceptible genotype were quite short suggesting a high level of inoculum in cassava debris from previous crops was being disseminated from plant debris via splashing rain, and that high relative humidity created a favourable environment for conidia germination and infection. This report supports the observation made in all the three trials, where TMS 30211 and TMS 30001 had cankers high up on the stem and zero score was mostly recorded in the third trial during which rainfall was low. This is also in line with the findings of Ikotun and Hahn (1991), which revealed that 30211 and TMS 30001 had cankers high up on the stem implying that they were infected later in life. This will lead to more disease-free stem which will be available for the propagation of these cultivars in the next growing season. This means that the spread of CAD on the farms will be reduced and 
TABLE 2. Size of cankers on maturing stem (SCM) at 9 months after planting at Ihiagwa in Nigeria

\begin{tabular}{llll}
\hline Variety & & $\mathrm{SCM}\left(\mathrm{mm}^{2}\right)$ & \\
\cline { 2 - 4 } & $1^{\text {st }}$ trial $(2003 / 04)$ & $2^{\text {nd }}$ trial $(2004 / 05)$ & $3^{\text {rd }}$ trial $(2005 / 06)$ \\
\hline Akwakwuru & 7.70 & 24.7 & 0. \\
TMS 30555 & 6.80 & 31.6 & 0. \\
98/0510 & 6.50 & 7.2 & 0. \\
Nwageri & 6.17 & 26.7 & 0. \\
97/3200 & 5.90 & 21.9 & 0. \\
92/0067 & 5.53 & 17 & 0. \\
96/1642 & 4.90 & 17.4 & 9.7 \\
92/0326 & 4.53 & 23.9 & 0. \\
91/02324 & 4.40 & 42.2 & 0. \\
TMS 30572 & 4.23 & 24.1 & 5.1 \\
NR 8082 & 3.80 & 26.9 & 0.0 \\
TMS 30211 & 3.73 & 12.9 & 6.3 \\
NR 8212 & 3.67 & 13.2 & 0. \\
TMS 91934 & 3.40 & 16.5 & 8.2 \\
Nwa0cha & 3.20 & 25.4 & 0. \\
TMS 30001 & 2.37 & 22.4 & 0. \\
TME 117 (Isuni) & 2.20 & 26.2 & 0. \\
TMS 4(2)1425 & 1.80 & 3.8 & 0. \\
LSD 0.05 & 1.74 & 21.5 & 1.6 \\
\hline
\end{tabular}

Means followed by the same alphabet in the same column are not significantly different according to $L S D(P<0.05)$

TABLE 3. Rainfall (mm) data for the years of 2003, 2004, 2005 and 2006 at Ihiagwa in Nigeria

\begin{tabular}{lllll}
\hline Month & \multicolumn{3}{c}{ Year } \\
\cline { 2 - 5 } & 2003 & 2004 & 2005 & 2006 \\
\hline January & 10.9 & 42.3 & 1.9 & 20.6 \\
February & 27.9 & 92.6 & 15.6 & 60.5 \\
March & 90.4 & 136.9 & 30.8 & 40 \\
April & 241.7 & 73.3 & 85 & 80 \\
May & 265.6 & 278.1 & 160.5 & 120 \\
June & 280.5 & 277.4 & 200.5 & 220 \\
July & 391.5 & 439.5 & 220 & 280 \\
August & 358.7 & 179.2 & 185.4 & 190 \\
September & 293.5 & 476.4 & 209.1 & 2150 \\
October & 100.5 & 123.8 & 151 & 20 \\
November & 40.9 & 50.6 & 40 & 13 \\
December & 18 & 0.2 & 5 & 1389.1 \\
Total & 2120.1 & 2170.3 & 1224.8 & 115.8 \\
Mean & 176.7 & 2170.3 & 102.1 & \\
Year & $2003 / 04$ & $2004 / 05$ & $2005 / 06$ & \\
Total & 2807.3 & 1550.7 & 1436.2 & 119.68 \\
Mean & 200.52 & 129.23 & & \\
\hline
\end{tabular}

Source: Imo state Meterological office 
healthy cassava stands will be produced. In all the trials, TMS 91934 had cankers close to the ground, $225 \mathrm{~mm}$ ( first trial), $783.3 \mathrm{~mm}$ (second trial), $50.7 \mathrm{~mm}$ ( third trial), and 96/1642 also had cankers close to the ground in the first trial and third trials.

The cultivars which had cankers close to the ground presented evidence that they were infected earlier in life. These cankers may serve as entry-points for other pathogens. Lozano and Booth (1974) and Akinyele and Ikotun (1989) reported that cankers serve as entry-points for such pathogens as Agrobacterium manihoti that cause crown gall disease in South America, as well as stem, root and tuber-rotting organisms such as Sphaerostible repens and Armillaria mellea. The presence of these pathogens leads to secondary infections, which lead to total loss of both yield and planting materials.

In all the trials, TMS 4(2)1425 and TMS 30211 had the smallest canker size on whole plant, young stems, shoots and maturing stems. The implication is that cultivars had higher resistance to anthracnose and can be recommended for further improvement through breeding. This is in line with Ikotun and Hahn, (1991) who reported TMS 30211 among the cultivars which had the smallest canker size and further stated that plants producing smaller-size lesions survive much longer and mature and produce flowers needed for breeding for improving resistance to CAD and other diseases.

Cultivars Akwakwuru, 98/0510, TMS 30572, TMS 30555, Nwaocha, TME 117 (Isun), 91/02324, 96/1642 and TMS 91934 had the largest canker size on whole plant, young stem, shoot and maturing stem. This is in line with Ikotun and Hahn (1991) and Fokunang et al. (2001) who reported that TME 117 and TMS 30572 had the largest cankers on maturing stem, and TMS 30211 had the smallest mean cankers on whole plant, shoot, young stem and maturing stem. Deeper cankers can block translocation of vital nutrients to active growing regions (IITA, 1990). These cultivars, therefore, had low resistance to anthracnose and are not recommended for use on the farms to the local farmers.

\section{REFERENCES}

Akinyele, J.B. and Ikotun, T. 1989. Microorganisms associated with cassava tuber rot: In Root, Tuber and Plantain Improvement Program, IITA, Ibadan, Nigeria. Annual Report. pp. 16-18.

Chandrasekharan, N.M., Ramanatha, M.M., Suharban, M. and Sukumara, A.V. 1979. Athracnose of cassava -A new record for India. Current Science 48: 443pp.

CIAT. 1977. Annual report, Cali, Colombia. From Muimba-Kankolongo, A. 1982. Predeposition of cassava plants to infection by Colletotrichum manihotis Henn. and some factors involved in the initiation of Anthracnose disease. Master of Philosophy Thesis; Department of Crop Protection and Environmental Biology, University of Ibadan, Ibadan, Nigeria. 242 pp.

FAO, 2009. FAOSTAT. Rome, Italy. (C) FAO Statistics Division 2007/09 September.

Fokunang, C.N., Akem, C.N., Ikotun, T. and Dixon, A.G.O. 1999. Effect of planting season on cassava anthracnose disease development. Crop protection 18:407-413.

Fokunang, C.N., Akem, C.N., Ikotun, T. and Dixon, A.G.O. 1999a. Effect of planting season on Cassava anthracnose disease development Crop Protection 18:407-413.

Fokunang, C.N., Akem, C.N., Ikotun, T., Dixon, A.G.O. and Tembe, E.A. 1999b. Seed survival and transmission of cassava anthracnose disease, and seed treatment effect on seeding growth. Pakistan Journal of Biological Science 2:849 - 854.

Fokunang,C.N., Dixon, A.G.O., Ikotun, T., Asiedu, R., Tembe, E.A. and Akem, C.N. 2001. In vitro, greenhouse and field assessments of cassava lines for resistance to anthracnose disease caused by Colletotrichum gloeosporioides f.sp.manihotis Mycopathologia 154:191-198.

Hahn, S.K., Terry, E.R., Leuschner, K. and Singh, T.P. 1981. Strategies of cassava improvement for resistance to major economic diseases for the 1980's. Terry, E.R., Oduro, K.A. and Caveness, F. (Eds.), pp. 25-28. Proceeding of 
$1^{\text {st }}$ Triennial Root Crops Symposium of the International Society for Tropical Root Crops, Africa Branch. IITA, Ibadan, Nigeria.

IITA, 1990. Cassava in Tropical Africa. A Reference Manual. IITA, Ibadan, Nigeria. 108pp.

Ikotun, T. and Hahn, S.K. 1991. Screening cassava cultivars for resistance to the cassava anthracnose disease (CAD). In: Proceedings of the $9^{\text {th }}$ Symposium of the Root Crops, 20 26 October 1991, Accra, Ghana. pp. 178-183.

Lozano, J.C. and Booth, R.H. 1974. Diseases of cassava. Pest Articles and News Summaries (PANS) 20:30-54.

Makambila, C. 1978. L'anthracnose du manoic en Republique populaire du Congo. In: Diseases of Tropical Food Crops.Maraite, H. and Meyer, J.A. (Eds.), pp. 61-68. Proceeding of an International symposium. U.L.C. Louvainla- Neuve, Belgium.

Makambila, C. 1987. Interactions between Pseudotheraptus devastans, Colletotrichum manihotis temperature and relative humidity in the development of anthracnose in cassava. In: Tropical Root Crops. Proceedings of the $3^{\text {rd }}$ Symposium of International Society for Tropical Root Crop - African Branch, held in Owerri, Nigeria.

Massenot, M. and Raynal, G. 1973. Les maladies des legumineuses fourrageres. I. Les anthracnose provuquees par les melanconiales. Annual Phytopathology 5: 83100.
Ngeve, J.M., Dixon, A.G.O. and Nukenine, E.N. 2005. The influence of host genetype $x$ environment interactions on response of cassava anthracnose disease in diverse agroecologies in Nigeria. African Crop Science Journal 13:1-11.

Obilo, O.P., Ikotun, B., Ihejirika, G.O. and Ibeawuchi, I.I. 2009. Reaction of selected cassava cultivars to cassava anthracnose disease (CAD) in Nigeria. Journal of Animal and Plant Sciences 3:186 - 193.

Okechukwu, R.U., Dixon, A.G.O., Akoroda, M.O, Mwangi, M. and Bandyopadhyay. 2009. Root rot resistance in new cassava varieties introduced to farmers in Nigeria. Cambridge University Press. Expl Agric. 45:15-24.

Onyeka, T.J, Dixon, A.G.O. and Ekpo, E.J.A. 2005. Assessment of laboratory methods for evaluating cassava genotypes for resistance to root rot disease. Mycopathologia 159: 461467.

Theberge, R.L. 1985. Common African Pest and Diseases of Cassava, Yam, Sweet Potato and Cocoyam. International Institute of Tropical Agriculture, Ibadan Nigeria. 107pp .

Terry, E.R. and Oyekan, J.O. 1976. Cassava diseases in Africa reviewed. Span 19:116-118.

Van der Bruggen, P. and Maraite, H. 1987. Histopathology of Cassava Anthracnose Disease cause Colletotrichum gloeosporioides f.sp.Manihotis. Parastica. 43:321. 